\title{
Stratification, freezing, and drying effects on germination and seedling growth of Altai wildrye
}

\author{
J.T. ROMO
}

\section{Abstract}

Altai wildrye (Leymus angustus (Trin.)Pilger) is recommended for late season forage and stabilization or improvement of salt affected land in the northern Great Plains. Establishment from seeding is erratic, perhaps due to environmental extremes that occur in the seedbed. Objectives of this study were to evaluate the effect of temperature and moisture variation on germination, solute leakage from seeds, and etiolated growth of seedlings of this perennial grass. Seeds were subjected to 5 preincubation treatments: stratification $\left(5^{\circ} \mathrm{C}\right.$ ) (STR); stratification plus drying $\left(30^{\circ}\right.$ C) (STR-D); stratification plus freezing $\left(-10^{\circ} \mathrm{C}\right.$ )(STR-FR); cooldry storage $\left(5^{\circ} \mathrm{C}\right)(\mathrm{COOL})$; and laboratory storage (LAB). After pretreatment, seeds were incubated at 10 and $20^{\circ} \mathrm{C}$ in a gradient of osmotic potentials ranging from 0.0 to $-1.59 \mathrm{MPa}$. Solute leakage from seeds and seedling growth were also assessed following pretreatment. Germination was higher and more rapid over the range of osmotic potentials at $20^{\circ} \mathrm{C}$ than at $10^{\circ} \mathrm{C}$ with germination poorest in STR-FR. In the absence of water stress, leakage of solutes was $21 \%$ lower from stratified seeds than unstratified seeds; leakage at $\mathbf{- 0 . 4 8} \mathrm{MPa}$ was similar across pretreatments. Compared to the other pretreatments, root and shoot growth of seedlings following STR-FR were reduced 34 and $76 \%$ at $-0.48 \mathrm{MPa}$. Negative effects of STR-FR were reflected in restricted germination and growth, but not in solute leakage. Results of this study and others suggest that efforts to minimize temperature extremes in the seedbed could improve germination and seedling growth of Altai wildrye.

Key Words: Leymus angustus, water stress, root growth, and shoot growth

Altai wildrye (Leymus angustus (Trin.) Pilger), introduced to North America from Asia, is recommended for use as fall and winter pasture and for stabilization or improvement of saltaffected soils (Lawrence et al. 1960; Lawrence and Heinrichs 1970, 1974; McElgunn and Lawrence 1973; Currie et al. 1986). Despite its high yield and excellent quality forage (Lawrence and Heinrichs 1970, Lawrence et al. 1980, Kilcher and Looman 1983) many

\footnotetext{
Author is assistant professor, range ecology, Department of Crop Science and Plant Ecology, University of Saskatchewan, Saskatoon, Canada S7N 0W0.

Funding for this research provided by the Department of Crop Science and Plant Ecology, University of Saskatchewan. The author thanks Drs. M. Devine, M.R. Haferkamp, T. Lawrence, and R.E. Redmann for critical reviews of the manuscript, and $\mathrm{C}$. Romo for preparing graphics.

Manuscript accepted 8 June 1989.
}

producers are reluctant to incorporate it into their forage systems, because of inconsistent establishment. This inconsistency may be related to microenvironmental influences on seeds before they germinate.

Temperature extremes and moisture deficits are major factors influencing the germination, growth, and survival of seedlings on the northern Great Plains (White and Horner 1943, White and Currie 1980, White 1984). However, we have a poor understanding of the effects of environmental extremes on Altai wildrye seeds, their germination, and seedling growth. The objectives of this study were to evaluate the effect of temperature and moisture variation on germination, solute leakage from seeds, and etiolated growth of Altai wildrye seedlings.

\section{Materials and Methods}

'Prairieland' Altai wildrye seed was supplied by Dr. T. Lawrence of Agriculture Canada Research Station in Swift Current, Saskatchewan. At the time of this experiment seeds were approximately 10 months old. Throughout this study seeds were subjected to 5 preincubation treatments. Treatments included: 1 . cool-moist $\left(5^{\circ}\right.$ C) stratification for $\mathbf{4 8}$ hours (STR)-this treatment simulated cool-moist conditions in the seedbeed; 2 . cool-moist stratification for 48 hours followed by drying at $30^{\circ} \mathrm{C}$ for 8 hours (STR-D) - this treatment simulated cool-moist conditions of the seedbed followed by a short warming and drying period; 3 . cool-moist stratification for 48 hours followed by storage of seeds at $-10^{\circ} \mathrm{C}$ for 8 hours (STR-FR)-this simulated cool-moist conditions with temperatures falling below freezing for a short period; 4. cool-dry $\left(5^{\circ} \mathrm{C}\right)$ storage of seeds for 48 hours (COOL) - this simulated cool-dry conditions of a seedbed, and; 5 . laboratory storage (LAB).

All pretreatments were applied to seeds in Petri dishes in which a \#4 Whatman filter paper disc had been placed. For stratification treatments, $7 \mathrm{~mL}$ of distilled water was added to dishes, lids were replaced, and seeds were incubated at $5^{\circ} \mathrm{C}$ in darkness. After pretreatment, the moisture content of 4 samples of 25 seeds was determined after drying for 48 hours at $80^{\circ} \mathrm{C}$ (Table 1 ).

\section{Experiment 1-Temperature and Water Stress Effects on Ger- mination}

Osmotic solutions were prepared by adding polyethylene glycol (PEG) (M.W. 20,000) to distilled water. Average osmotic poten- 
Table 1. Mean molsture content expressed as percent of oven dry weight for Altai wildrye seeds following 5 pretreatments.

\begin{tabular}{|c|c|c|c|c|c|}
\hline \multirow{2}{*}{ Experiment } & \multicolumn{5}{|c|}{ Pretreatment } \\
\hline & STR & STR-D & STR-FR & COOL & LAB \\
\hline $\begin{array}{l}\text { Germination } \\
\text { Solute leakage } \\
\text { Seedling growth }\end{array}$ & $\begin{array}{l}95.2 \\
90.4 \\
93.9\end{array}$ & $\begin{array}{l}43.3 \\
38.5 \\
42.5\end{array}$ & $\begin{array}{l}96.4 \\
98.8 \\
95.3\end{array}$ & $\begin{array}{l}9.9 \\
9.9 \\
8.8\end{array}$ & $\begin{array}{r}10.0 \\
10.0 \\
8.2\end{array}$ \\
\hline
\end{tabular}

tials and the standard error $(n=4)$ of these solutions, determined using a Wescor vapor pressure osmometer, were $-0.10 \pm 0.01$, $-0.35 \pm .01,-0.69 \pm 0.01,-0.99 \pm .02,-1.22 \pm 0.02$, and $-1.59 \pm$ $0.02 \mathrm{MPa}$. Distilled water was used as the control $(0.0 \mathrm{MPa})$. A \#4 Whatman filter paper disc was placed in each Petri dish and $10 \mathrm{~mL}$ of osmotic solutions were added. Seeds were removed from the pret reatment, placed in the osmotic potential dishes, the lids were replaced, and the Petri dishes were enclosed in plastic bags to prevent desiccation. Seeds were incubated in darkness at 10 and $20^{\circ} \mathrm{C}$. Germination was recorded at 2 -day intervals through 20 days and a final count was made at 30 days. A seed was considered germinated when both the radicle and plumule were at least $5 \mathrm{~mm}$ long. Within temperatures, treatments were factorially applied to 4 replicates of 25 seeds using osmotic potentials and pretreatments as main effects in a complete randomized block design. Average germination rates (\%/day) were calculated according to Maguire (1962). Total germination percentage and germination rate were transformed with arcsin $\sqrt{\hat{p}}$ and subjected to analysis of variance (Snedecor and Cochran 1980). Regression equations were derived using untransformed data for each temperature and pretreatment and the best fit regression equation was selected; intercepts and regression coefficients were compared within temperatures and germination parameters (Steel and Torrie 1980).

\section{Experiment 2-Leakage of Solutes from Seeds}

Lots of 25 seeds were counted and stored in paper envelopes in the laboratory until being subjected to the pretreatments described above. Seeds were then transferred to $250 \mathrm{~mL}$ Erlenmeyer flasks containing $15 \mathrm{~mL}$ of PEG solution with a mean osmotic potential of $-0.48 \mathrm{MPa}$ (s.e. $\pm 0.03, \mathrm{n}=4)$ or distilled water $(0.0 \mathrm{MPa})$. The Erlenmeyer flasks were covered with aluminum foil to prevent evaporation and placed on a rotating shaker at $15^{\circ} \mathrm{C}$ in darkness. From previous trials it was determined that dilution of solutions was necessary before UV-absorbance could be determined accurately. For this reason $125 \mathrm{~mL}$ of distilled water was added to each flask after 36 hours of shaking, and the flasks were replaced on the shaker for an additional 12 hours. After the 48-hour incubation period, approximately $2.0 \mathrm{~mL}$ of solution was removed from each flask and the absorbance was determined at $280 \mathrm{~nm}$. th a Bausch and Lomb Spectronic 710 spectrophotometer. This solution was returned to the flask and frozen at $-70^{\circ} \mathrm{C}$ for 24 hours to destroy membrane integrity. Flasks were then removed from the freezer, placed on a shaker at $15^{\circ} \mathrm{C}$, and allowed to thaw for 18 hours. Another $2.0 \mathrm{~mL}$ of solution was removed from the flasks, the absorbance was determined, and the relative leakage ratio (RLR) was calculated (Redmann et al. 1986). Treatments were applied factorially in a complete randomized block design with 4 replications. RLR data were transformed with arcsin $\sqrt{\hat{p}}$ and subjected to analysis of variance (Snedecor and Cochran 1980).

\section{Experiment 3-Etiolated Seedling Growth}

Lots of 50 seeds were subjected to the 5 pretreatments and then transferred to Petri dishes containing a $\$ 4$ Whatman filter paper disc, and $10 \mathrm{~mL}$ of PEG solution or distilled water. Osmotic potential of the PEG solution averaged $-0.48 \mathrm{MPa}$ (s.e. \pm 0.03 , $\mathrm{n}=4)$; distilled water was used as the control $(0.0 \mathrm{MPa})$. Seeds were incubated in darkness at $15^{\circ} \mathrm{C}$ and germination was checked daily. On each check if there were fewer than 5 germinated seeds, the germinated seeds were removed. On the first day that at least 5 seeds had germinated, all ungerminated seeds were removed, and the 5 seedlings were allowed to grow for 5 days. Thus, 5 seedlings of equal physiologic age were measured for growth. At the end of the growth period, the seedlings were removed and the roots and shoots were separated, dried for 48 hours at $80^{\circ} \mathrm{C}$, and weighed. Treatments were applied factorially in a complete randomized block design using 4 replications, and root and shoot weights were subjected to analysis of variance.

\section{Results}

\section{Germination}

Germination was higher and more rapid, and occurred over a wider range of osmotic potentials, at $20^{\circ} \mathrm{C}$ than at $10^{\circ} \mathrm{C}$ (Figs. 1
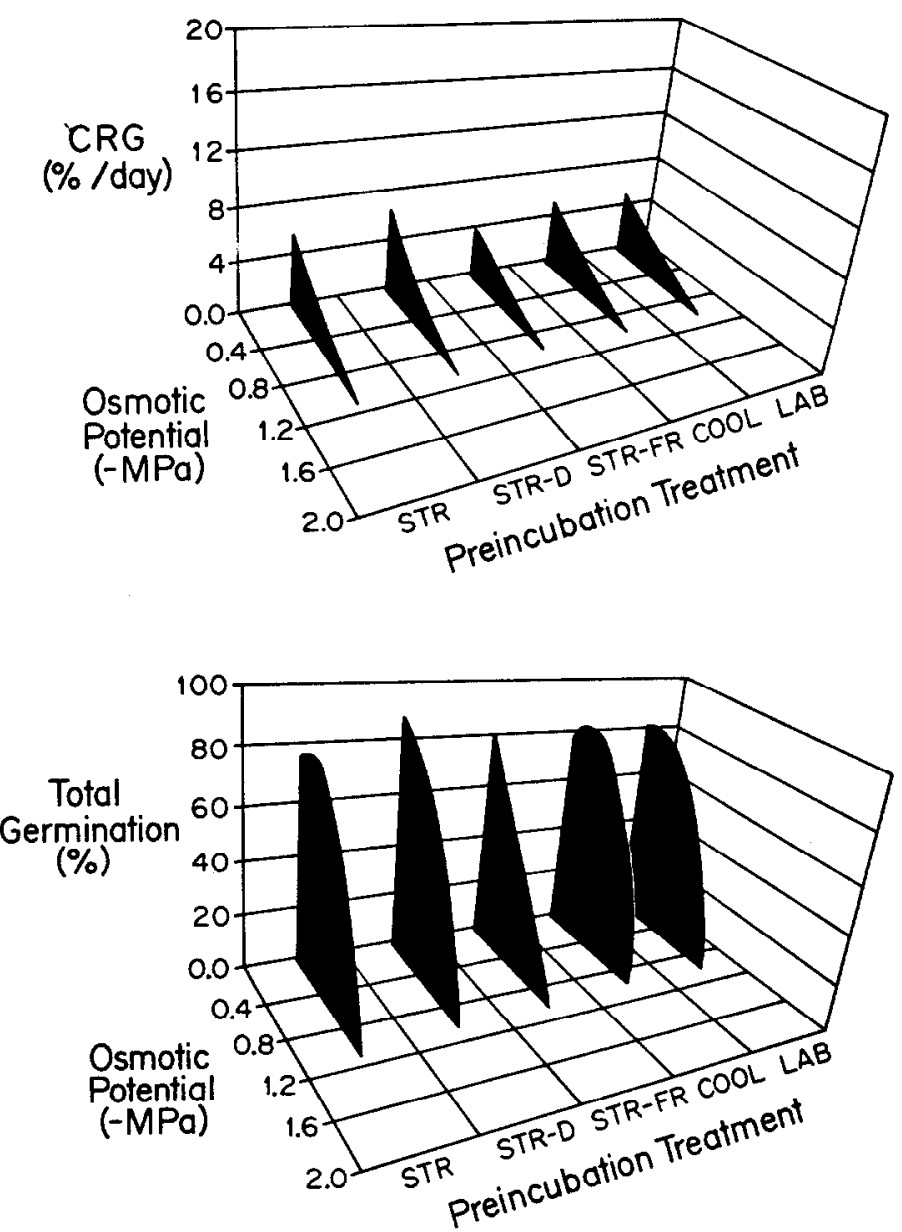

Fig. 1. Response curves for total germination and coefficient of rate of germination (CRG) of Altai wildrye seeds subjected to 5 preincubation treatments and incubated at $10^{\circ} \mathrm{C}$ in a gradient of osmotic potentials.

and 2, (Table 2). Within temperatures the interaction of pretreatment $\times$ osmotic potential significantly $(P<0.05)$ influenced total germination and rate of germination. At both 10 and $20^{\circ} \mathrm{C}$ total germination and germination rate were lowest over the range of osmotic potentials for STR-FR.

At $10^{\circ} \mathrm{C}$ germination rate-osmotic potential relationships were linear for COOL, LAB, and STR-FR and the response curves for COOL and LAB pretreatments were similar (Table 2). The regression equations relating total germination to osmotic potential were similar for STR, COOL, and LAB pretreatments; total germina- 


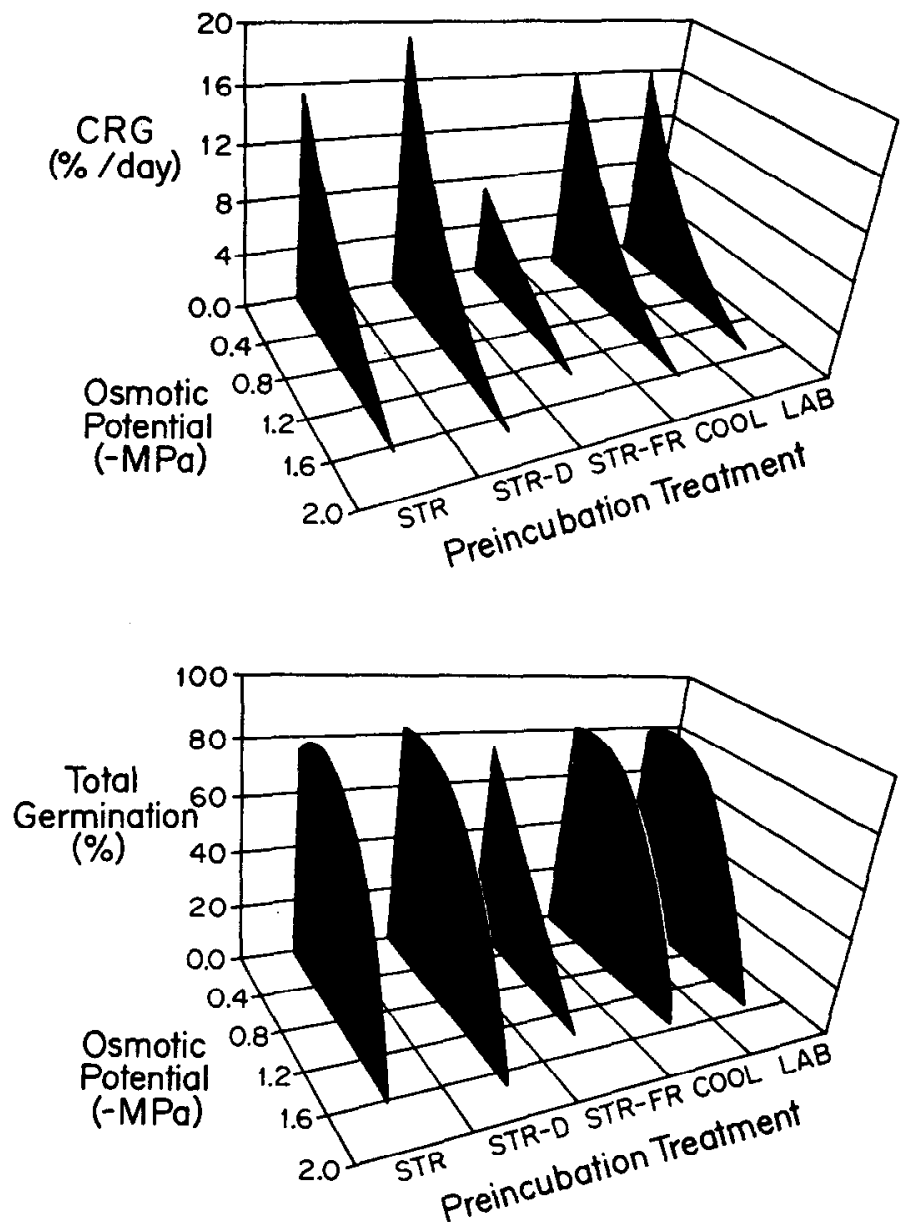

Fig. 2. Response curves for total germination and coefficient of rate of germination (CRG) of Altai wildrye seeds subjected to 5 preincubation treatments and incubated at $20^{\circ} \mathrm{C}$ in a gradient of osmotic potentials.

tion after STR-FR decreased linearly as osmotic potentials declined.

At $20^{\circ} \mathrm{C}$ the osmotic stress produced a linear decrease in total germination and germination rate of the STR-FR pretreatment (Table 2). The intercept of the germination rate regression equation for STR-FR was also significantly $(P \leq 0.05)$ lower than the other pretreatments. This indicates that the effects of freezing were sufficient to eliminate any capacity to resist external water stress. Osmotic potential effects on the decline in germination rate were similar for STR-D, COOL and LAB.

\section{Solute Leakage From Seeds}

The osmotic potential $\times$ pretreatment interaction significantly $(P \leq 0.05)$ influenced the relative leakage ratio (RLR) for seeds (Table 3). Seeds that had been stratified had lower RLR's than unstratified seeds at 0.0 MPa, with STR-D being lowest. RLR was significantly $(P \leq 0.05$ ) higher at $-0.48 \mathrm{MPa}$ than at $0.0 \mathrm{MPa}$, but there were no differences between pretreatments.

\section{Etiolated Seedling Growth}

The interacting effects of osmotic potential and pretreatment significantly ( $P \leq 0.05$ ) influenced etiolated root and shoot growth of seedlings (Table 4). Root weights were similar for all pretreatments at 0.0 MPa. However, root weight for STR-FR was lower than the other pretreatments at $-0.48 \mathrm{MPa}$. Root weights following STR and STR-D were greater at $-0.48 \mathrm{MPa}$ than $0.0 \mathrm{MPa}$, but they were similar at 0.0 and $-0.48 \mathrm{MPa}$ for COOL and $\mathrm{LAB}$
Table 2. Regression equations for relationships between osmotic potential effects on total germination and germination rate of Altai wildrye following pretreatment.

\begin{tabular}{|c|c|c|c|c|c|}
\hline $\begin{array}{l}\text { Pretreat- } \\
\text { ment }\end{array}$ & $\begin{array}{l}\text { Tempera- } \\
\text { ture }\left({ }^{\circ} \mathrm{C}\right)\end{array}$ & Regression equation & & & $\mathbf{R}^{2}$ \\
\hline $\begin{array}{l}\text { STR } \\
\text { STR-D } \\
\text { STR-FR } \\
\text { COOL } \\
\text { LAB }\end{array}$ & 10 & $\begin{array}{l}\text { Germination rate }(\% / \text { day }) \\
Y=6.1+5.6 \mathrm{X}-0.6 \mathrm{X}^{21} \\
Y=7.2+9.2 \mathrm{X}-2.8 \mathrm{X}^{2} \\
Y=4.2+3.8 \mathrm{X} \\
Y=5.7+5.0 \mathrm{X} \\
Y=5.6+4.9 \mathrm{X}\end{array}$ & $\begin{array}{l}\mathbf{a}^{2} \\
\mathbf{a} \\
\mathbf{a} \\
\mathbf{a} \\
\mathrm{a}\end{array}$ & $\begin{array}{l}\mathrm{A}^{3} \\
\mathrm{~B} \\
\mathrm{C} \\
\mathrm{D} \\
\mathrm{D}\end{array}$ & $\begin{array}{l}0.95 \\
0.96 \\
0.92 \\
0.96 \\
0.94\end{array}$ \\
\hline $\begin{array}{l}\text { STR } \\
\text { STR-D } \\
\text { STR-FR } \\
\text { COOL } \\
\text { LAB }\end{array}$ & & $\begin{array}{l}\text { Total germination }(\%) \\
Y=77.1-39.0 X-81.4 X^{2} \\
Y=88.6+1.6 X-62.1 X^{2} \\
Y=83.4+70.7 X \\
Y=76.1-43.1 X-93.9 X^{2} \\
Y=82.1-20.5 X-78.7 X^{2}\end{array}$ & $\begin{array}{l}\mathbf{a} \\
\mathbf{a} \\
\mathbf{a} \\
\mathbf{a} \\
\mathbf{a}\end{array}$ & $\begin{array}{l}\text { A } \\
\mathbf{B} \\
\mathbf{C} \\
\mathbf{A} \\
\mathbf{A}\end{array}$ & $\begin{array}{l}0.92 \\
0.96 \\
0.91 \\
0.95 \\
0.92\end{array}$ \\
\hline $\begin{array}{l}\text { STR } \\
\text { STR-D } \\
\text { STR-FR } \\
\text { COOL } \\
\text { LAB }\end{array}$ & 20 & $\begin{array}{l}\text { Germination rate }(\% / \text { day }) \\
Y=16.2+11.5 X+1.2 X^{2} \\
Y=19.9+18.7 X-4.3 X^{2} \\
Y=7.6+5.3 X \\
Y=16.7+16.7 X+4.1 X^{2} \\
Y=16.4+16.8 X+4.2 X^{2}\end{array}$ & $\begin{array}{l}\mathbf{a} \\
\mathbf{a} \\
\mathbf{b} \\
\mathbf{a} \\
\mathbf{a}\end{array}$ & $\begin{array}{l}\mathbf{A} \\
\mathbf{B} \\
\mathbf{C} \\
\mathbf{B} \\
\mathbf{B}\end{array}$ & $\begin{array}{l}0.92 \\
0.96 \\
0.86 \\
0.93 \\
0.90\end{array}$ \\
\hline $\begin{array}{l}\text { STR } \\
\text { STR-D } \\
\text { STR-FR } \\
\text { COOL } \\
\text { LAB }\end{array}$ & & $\begin{array}{l}\text { Total germination }(\%) \\
Y=75.1-44.1 X+50.7 \mathrm{X}^{2} \\
Y=83.5-15.1 \mathrm{X}+32.2 \mathrm{X}^{2} \\
Y=77.2+50.8 \mathrm{X} \\
Y=81.3-16.5 \mathrm{X}+38.4 \mathrm{X}^{2} \\
Y=79.5+29.3 \mathrm{X}+48.6 \mathrm{X}^{2}\end{array}$ & $\begin{array}{l}\mathbf{a} \\
\mathbf{a} \\
\mathbf{a} \\
\mathbf{a} \\
\mathbf{a}\end{array}$ & $\begin{array}{l}\mathbf{A} \\
\mathbf{B} \\
\mathbf{C} \\
\mathbf{B} \\
\mathbf{D}\end{array}$ & $\begin{array}{l}0.85 \\
0.85 \\
0.87 \\
0.85 \\
0.82\end{array}$ \\
\hline
\end{tabular}

' $\mathrm{X}$ is osmotic potential (-MPa).

${ }^{2}$ The same lower case letter within a parameter indicates non-significant $(P \leq 0.05)$ differences between intercepts of regression equations.

${ }^{3}$ The same upper case letter within a parameter indicates non-significant $(P \leq 0.05)$ differences between regression equations.

Table 3. Relative leakage ratio for Altai wildrye seeds subjected to 5 preincubation treatments.

\begin{tabular}{|c|c|c|c|c|c|c|}
\hline \multirow{2}{*}{$\begin{array}{l}\begin{array}{l}\text { Osmotic } \\
\text { potential }\end{array} \\
\text { (MPa) }\end{array}$} & \multicolumn{6}{|c|}{ Pretreatment } \\
\hline & STR & STR-D & STR-FR & $\mathrm{COOL}$ & LAB & $\mathbf{S E}^{1}$ \\
\hline $\begin{array}{r}0.00 \\
-0.48\end{array}$ & $\begin{array}{l}0.528 \\
0.870\end{array}$ & $\begin{array}{l}0.499 \\
0.861\end{array}$ & $\begin{array}{l}0.540 \\
0.868\end{array}$ & $\begin{array}{l}0.675 \\
0.868\end{array}$ & $\begin{array}{l}0.651 \\
0.866\end{array}$ & 0.028 \\
\hline
\end{tabular}

ISE = Standard Error

Table 4. Mean root and shoot weights for Altai wildrye seedlings after seeds were subjected to 5 preincubation treatments and grown for 5 days at $15^{\circ} \mathrm{C}$ in darkness.

\begin{tabular}{|c|c|c|c|c|c|c|}
\hline \multirow{2}{*}{$\begin{array}{l}\begin{array}{l}\text { Osmotic } \\
\text { potential }\end{array} \\
(\mathrm{MPa})\end{array}$} & \multicolumn{6}{|c|}{ Pretreatment } \\
\hline & STR & STR-D & STR-FR & COOL & LAB & \\
\hline & \multicolumn{5}{|c|}{ Root Weight (mg) } & SE1 \\
\hline $\begin{array}{r}0.00 \\
-0.48\end{array}$ & $\begin{array}{l}18.4 \\
23.9\end{array}$ & $\begin{array}{l}18.1 \\
20.9\end{array}$ & $\begin{array}{l}21.4 \\
14.9\end{array}$ & $\begin{array}{l}21.8 \\
23.5\end{array}$ & $\begin{array}{l}21.1 \\
22.3\end{array}$ & 0.99 \\
\hline \multicolumn{7}{|c|}{ Shoot Weight (mg) } \\
\hline-0.48 & 29.1 & 26.2 & 6.4 & 26.3 & 27.0 & 0.51 \\
\hline
\end{tabular}

ISE = Standard Error

pretreatments.

Shoot weights were similar between treatments at $0.0 \mathrm{MPa}$ (Table 4). Shoot weight for STR-FR was $76 \%$ lower at $-0.48 \mathrm{MPa}$ than $0.0 \mathrm{MPa}$, and this weight was lower than the remaining pretreatments. In contrast shoot weight for STR was $25 \%$ higher at 
$-0.48 \mathrm{MPa}$ than at $0.0 \mathrm{MPa}$.

\section{Discussion}

An apparent reduction in vigor, caused by stratifying seeds and subjecting them to $-10^{\circ} \mathrm{C}$, was expressed in reduced germination and seedling growth. Crocker and Barton (1957) concluded that low vigor seeds may need more water to germinate than high vigor seeds, and Hegarty (1978) contended that loss of vigor precedes loss of viability. Furthermore, seeds with reduced vigor may not germinate over as broad a range of conditions as high vigor seeds (Abdul-Baki and Anderson 1972). Under conditions of increasing moisture stress, the negative effects of STR-FR became more pronounced as indicated by reduced germination and seedling growth under water stress. On the other hand, stratifying seeds or stratification and dehydration either improved or had no effect on germination and seedling growth.

Wilson et al. (1974) reported that exposing seeds of several rangeland grasses to winter conditions increased the rate of germination of seeds when they were incubated in the laboratory. However, germination time increased when the soil temperatures were coldest (approximately $-5^{\circ} \mathrm{C}$ ) (Wilson et al. 1974). This same reaction to freezing temperatures was found in the present experiment.

Hydration and dehydration treatments increased germination of crested wheatgrass (Agropyron desertorum) (Maynard and Gates 1963) and Lehmann lovegrass (Eragrost is lehmanniana) (Haferkamp and Jordan 1977). Stratifying seeds and stratification followed by drying also improved the rate of germination for Altai wildrye. It is proposed that the ATP synthesized during stratification was not degraded by dehydration and additional ATP was formed upon rehydration (Haferkamp et al. 1977).

Absorbance at $280 \mathrm{~nm}$ gives an indication of the leakage of UV-absorbing cytoplasmic compounds from the cells (Morris 1987). Leakage is rapid during the early stages of imbibition until the phospholipid membranes become intact (Simon 1984). Thus, the lower RLR at $0.0 \mathrm{MPa}$ for stratified seeds is attributed to membrane repair that occurred during stratification. In contrast, the unstratified seeds (COOL and LAB) were probably undergoing earlier stages of the membrane repair processes and leakage was higher (Hegarty 1978, Simon 1984). Leakage of UV-absorbing compounds from the seed appendages may have also contributed to the higher RLR for unstratified seeds. Higher RLR at -0.48 $\mathrm{MPa}$ than $0.0 \mathrm{MPa}$ is ascribed to less water availability, reduced rate of hydration and more solute leakage due to a reduction in the extent and rate of membrane repair. Seeds that hydrate slowly may deteriorate rather than progressing through the activation and repair phases (Hegarty 1978).

It is proposed that STR-FR damaged seeds through the mechanical effects caused by ice crystal formation and damage to membranes (Grout and Morris 1987); however, these damaging effects were not substantiated by solute leakage from seeds. This determination actually indicated an equal or better physiological condition than seeds subjected to the other pretreatments. These results underscore the need to document seedling growth in addition to germination.

Data from the present study and others (Lawrence and Kilcher 1972, McElgunn 1974, Young and Evans 1982) suggests that low temperatures play a role in the poor germination, growth, and establishment of Altai wildrye. When this grass is seeded it appears that precautions must be taken to minimize temperature extremes of the seedbed to maximize germination and growth. This study supports Lawrence and Kilcher's (1972) tenet that the slow emergence of Altai wildrye at low temperatures indicates that this species may not be expected to establish early in the spring like other grasses that are commonly seeded on rangeland. They suggested that delaying seeding until soils warm may be advantageous for stand establishment. Delaying seeding until warmer temperatures prevail may not only enhance the rate of germination, emergence, and seedling growth (Lawrence and Kilcher 1972, McElgunn 1974), but it may also limit the potential reduction in germination caused by freezing temperatures.

Delaying seeding may also be disadvantageous because it can shorten the potential period of growth caused by temperature or moisture limitations. Therefore cultural practices are paramount for germination and establishment of Altai wildrye. Seeding into cool seedbeds is probably the preferred alternative provided attempts are made to minimize temperature and moisture extremes. Creating rough seedbeds or seeding into grain stubble may be the preferred options because temperature fluctuations are likely to be less than on smooth seedbeds or sites devoid of vegetation (Evans and Young 1970, 1972; Hull 1970; Fowler 1983).

\section{Literature Cited}

Abdul-Baki, A.A., and J.D. Anderson. 1972. Physiological and biochemical deterioration of seeds. p. 283-315. In: T.T. Kozlowski (ed.). Seed biology, Vol. II. Academic Press, New York.

Crocker, $w$., and L.V. Barton. 1957. Physiology of seeds. Cronica Botanica Co., Waltham, Mass.

Currie, P.O., T.O. Hilken, and R.S. White. 1986. Field evaluation of five grasses grown on a saline soil. J. Range Manage. 39:386-388.

Evans, R.A., and J.A. Young. 1970. Plant litter and establishment of alien annual weed species in rangeland communities. Weed Sci. 18:697-702.

Evans, R.A., and J.A. Young. 1972. Microsite requirements for establishment of annual rangeland weeds. Weed Sci. 20:350-356.

Fowler, D.B. 1983. The effect of management practices on winter wheat survival and yield of winter wheat produced in regions with harsh winter climates. p. 238-282. In: D.B. Fowler, L.V. Gusta, A.E. Slinkard, and B.A. Hobin (eds.). New frontiers in winter wheat production. University of Saskatchewan Printing Services. Saskatoon.

Grout, B.W.W., and G.J. Morris. 1987. Freezing and cellular organization. p. 147-173. In: B.W.W. Grout and G.J. Morris (eds.). The effects of low temperatures on biological systems. Edward Arnold Pub., London.

Haferkamp, M.R., and G.L. Jordan. 1977. The effect of presowing seed treatments on germination of Lehmann lovegrass seeds. J. Range Manage. $30: 151-153$.

Haferkamp, M.R., G.L. Jordan, and K. Matsuda. 1977. Pre-sowing seed treatments, seed coats, and metabolic activity of Lehmann lovegrass seeds. Agron. J. 69:527-530.

Hegarty, T.W. 1978. The physiology of seed hydration and dehydration, and the relation between water stress and the control of germination: a review. Plant, Cell, Environ. 1:101-119.

Hull, A.C. Jr. 1970. Grass seedling emergence and survival from furrows. J. Range Manage. 23:421-424.

Kilcher, M.R., and J. Looman. 1983. Comparative performance of some native and introduced grasses in southern Saskatchewan, Canada. J. Range Manage. 36:654-657.

Lawrence, T., and D.H. Heinrichs. 1970. Pasture attributes of Altai wild ryegrass. Can. J. Plant Sci. 50:743-745.

Lawrence, T., and M.R. Kilcher. 1972. Emergence, seedling growth, and yield of Altai wild ryegrass and other grasses as influenced by soil temperature and fertility. Can. J. Plant Sci. 52:795-800.

Lawrence, T., and D.H. Heinrichs. 1974. Altai wild ryegrass for winter pasture. Can. J. Plant Sci. 54:581-584.

Lawrence, T., D.H. Heinrichs, and R.B. Carson. 1960. An evaluation of Atlai wild rye, Elymus angustus Trin., as a forage crop. Can. J. Plant Sci. 40:295-305.

Lawrence, T., H.C. Korven, and G.E. Winkleman, and F.G. Warder. 1980. The productivity and chemical composition of Altai wildryegrass as influenced by time of irrigation and time and rate of $\mathrm{N}$ fertilization. Can. J. Plant Sci. 60:1179-1189.

Maguire, J.D. 1962. Speed of germination-aid in selection and evaluation of seedling emergence and vigor. Crop Sci. 2:176-177.

Maynard, M.L., and D.H. Gates. 1963. Effects of wetting and drying on germination of crested wheatgrass seeds. J. Range Manage. 16:119-121.

McElgunn, J.D., and T. Lawrence. 1973. Salinity tolerance of Altai wild ryegrass and other forage grasses. Can. J. Plant Sci. 53:303-307. 
McElgunn, J.D. 1974. Germination response of forage grasses to constant and alternating temperatures. Can. J. Plant Sci. 54:265-270.

Morris, G.J. 1987. Direct chilling injury.p. 147-173. In: B.W.W. Grout and G.J. Morris (eds.). The effects of low temperatures on biological systems. Edward Arnold Pub., London.

Ott, L. 1977. An introduction to statistical methods and data analysis. Duxbury Press. North Scituate, Mass.

Redmann, R.E., J. Haraldson, and L.V. Gusta. 1986. Leakage of UVabsorbing substances as a measure of salt injury in leaf tissues of woody species. Physiol. Plant. 67:87-91.

Simon, E.W. 1984. Early events in germination. p. 77-115. In: D.R. Murray (ed.). Seed physiology. Vol. 2. Germination and reserve mobilization. Academic Press, New York.

Snedecor, G.W., and W.C. Cochran. 1980. Statistical methods. The Iowa State Univ. Press. Ames.
Steel, R.G.D., and J.H. Torrie. 1980. Principles and procedures of statistics. McGraw-Hill. New York.

White, R.S. 1984. Stand establishment: the role of seedling size and winter injury in early growth of three perennial grass species. J. Range Manage. 37:206-211.

White, R.S., and P.O. Currie. 1980. Morphological factors related to seedling injury in three perennial grasses. Can. J. Plant Sci. 60:141 1-1418.

White, W.J., and W.H. Horner. 1943. The winter survival of grass and legume plants in fall sown plots. Sci. Agr. 23:399-408.

Wilson, A.M., D.E. Wondercheck, and C.J. Gobel. 1974. Responses of range grass seeds to winter environments. J. Range Manage. 27:120-122.

Young, J.A, and R.A. Evans. 1982. Temperature profiles for germination of cool season range grasses. USDA Agr. Res. Serv. Pub. ARR-W-27. 